\title{
QAWA''ID AL-FIQHIYYAH ANALYSIS ON THE PROHIBITION OF MONOPOLY PRACTICES AND UNFAIR BUSINESS COMPETITION: A CRITICAL REVIEW
}

\author{
Ahmad Lutfi Rijalul Fikri* \\ Sharia Deparment, STIS Darul Falah Pagutan, Kota Mataram, Indonesia \\ Email: luthfi2311@gmail.com
}

* Corresponding author

DOI: 10.21154 /justicia.v18i1.2466

\begin{tabular}{l|l|l}
\hline Received: Jan 4, 2021 & Revised: March 5, 2021 & Approved: May 3, 2021 \\
\hline
\end{tabular}

Abstract: Qawā'id Al-Fiqhiyyah has an essential role in identifying new problems that arisen for analysis whether they are following Islamic law or not. The purpose of forming qa'idah-qa'idah in realizing Maqashid Sharia in protecting community property rights must be implemented in every statutory regulation or established by the government. This article examines and analyzes the prohibition of monopolistic practices and unfair business competition in Law No. 5 of 1999 by using several qawä'id al-fiqhiyyah. This paper's study is based on literature data analyzed using qualitative research methods with a multidisciplinary approach. This study concludes that the Law on the prohibition of monopoly and unfair business competition in Law No. 5 of 1999, which contains the prohibition of control of production and marketing, the prohibition of fraud/ conspiracy, and the prohibition of using a dominant position under qawä'id al-fiqhiyyah, among others, namely the rules that say Lâ Yahtakiru illâ Khâthi'un, an-Najasyu Harâmun, and atTas'îr. The conformity of the objectives of laws and regulations with the establishment of qa'idah-qa'idah is something that the government must maintain in the Draft Law on the Prohibition of Monopolistic Practices and Unfair Business Competition which is being programmed by the House of Representatives (DPR) of the Republic of Indonesia, so the purpose of being able to maintain community property rights can be implemented in this Law.

Qawa' 'id Al-Fiqhiyyah mempunyai peran penting dalam mengidentifikasi permasalahanpermasalahan baru yang muncul untuk dianalisis apakah sudah sesuai dengan hukum islam atau tidak. Tujuan pembentukan qa'idah-qa'idah dalam mewujudkan Maqashid Syariah dalam menjaga hak milik masyarakat merupakan sesuatu yang harus diimplemantasikan dalam setiap peraturan perundang-undangan yang telah maupun yang akan dibentuk oleh pemerintah. Artikel ini mengkaji dan menganalisa tentang larangan praktik monopoli dan persaingan usaha tidak sehat dalam Undang-undang No. 5 Tahun 1999 dengan menggunakan beberapa kaidah fikih. Kajian dalam tulisan ini berdasarkan data literatur yang dianalisa dengan menggunakan metode penelitian kualitatif dengan pendekatan multidisipliner. Kajian ini menyimpulkan bahwa Undang-Undang tentang larangan monopoli dan persaingan usaha tidak sehat dalam Undang-undang No. 5 Tahun 1999 yang berisi tentang larangan penguasaan produksi dan pemasaran, larangan kecurangan/ persekongkolan, dan larangan menggunakan posisi dominan sudah sesuai 
dengan qawä'id al-fighiyyah antara lain yaitu kaidah yang mengatakan Lâ Yahtakiru illâ Khâthi'un, an-Najasyu Harâmun, dan at-Tas'îr. Kesesuaian tujuan peraturan perundangundangan dengan tujuan dibentuknya qa'idah-qa'idah ini merupakan hal yang harus dipertahankan oleh pemerintah dalam Rancangan Undang-Undang tentang Larangan Praktik Monopoli dan Persaingan Usaha tidak Sehat yang sedang diprogramkan oleh Dewan Perwakilan Rakyat Republik Indonesia sehingga tujuan untuk menjaga hak milik masyarakat dapat diimplementasikan dalam Undang-Undang ini.

Keywords: Jurisprudence; Monopoly; Business Competition; Qawä'id Al-Fiqhiyyah.

\section{INTRODUCTION}

A market is a place of interaction between sellers and buyers, between consumers and producers, where prices are formed in the interaction between buyer demand and seller supply. Adiwarman A. Karim defines the market as a place or situation that brings together the demand (buyer) or supply (seller) for any goods, services, or resources. ${ }^{1}$ This supply and demand then form the market mechanism. The market mechanism determines the price level based on the power of demand and supply. ${ }^{2}$

According to capitalist economics, the market has a significant role in the economic system. The capitalist economy requires free markets to solve economic problems, from production, consumption to distribution. However, the free market's will in which there are a monopoly and unfair competition makes the economy worse and causes an increasingly uncertain market situation. This is because they assume that there will be an invisible hand that will bring the economy to the point of balance (equilibrium) without intervention from the government. Moreover, the global market's actual condition where trade between countries is indispensable so that government's role is significant in controlling the market mechanism.

Keynes stated that the best way to get a country out of a recession (demand and supply conditions below optimal capacity) is to involve the government significantly to push back the market demand and supply position through spending and investment policies. ${ }^{3}$ As one of the economic actors (government household), the government has an essential function in the economy, functioning as stabilization and creating economic stability, social politics, law, defense, and security. ${ }^{4}$

Adiwarman A. Karim, Ekonomi Mikro Islami (Jakarta: Rajawali Pers, 2010): 6.

Pratama Rahardja dan Mandala Manurung, Teori Ekonomi Mikro Suatu Pengantar, IV (Jakarta: LPFEUI, 1999): 26.

3 DJKN, “Intervensi Pemerintah Dalam Perekonomian: Bagian I Ringkasan Sejarah," accessed April 20, 2018, https://www.djkn.kemenkeu.go.id/artikel/baca/12670/Intervensi-Pemerintah-DalamPerekonomian-Bagian-I-Ringkasan-Sejarah.html.

4 Sumarni Marni, ""Intervensi Pemerintah" Antara Kebutuhan Dan Penolakan Di Bidang Ekonomi," Economica 1, no. 2 (May 21, 2015): 183-94, https:/ / doi.org/10.22202/economica.2013.v1.i2.118. 
In carrying out this function - especially in the economic field - the Republic of Indonesia government has issued Law Number 5 of 1999 on the Prohibition of Monopolistic Practices and Unfair Business Competition. To supervise the implementation of this Act, the government, through presidential decree number 75 of 1999, has formed the Business Competition Supervisory Commission to assess the functioning of the treaty, business activities, and abuse of dominant position, and to take action as an exercise of authority, and the administrative implementation.

To find out whether this law is under Islamic law or not, it is necessary to analyze the law using a multidisciplinary approach, namely using several qāwa'id al-fiqhiyyah, which are general conclusions from several problems of the Islamic law that can be used by ordinary people and jurists in finding solutions to legal problems arisen during society on various themes, i.e., worship, muamalah, and contemporary Islamic law issues. ${ }^{5}$. Qawä'id Al-Fiqhiyyah has a crucial role in analyzing the new phenomena that arisen in the economy, especially in economic problems in this study. This is because qawā'id al-fiqhiyhah is a theoretical abstraction, usually in the form of a short expressive statement, generally composed in a few words about the goals and objectives of the sharia. It is a statement of principle derived from a detailed reading of the fiqh rules on various themes. ${ }^{6}$

The development of Islamic economics leads us to examine the suitability of legal products produced by the government in the economic field with the existing Islamic economic principles. The finding of conformity with Islamic economics using qāwa'id al-fiqhiyyah is based on two reasons. First, it is a viable alternative approach to understand economics based on Islam's values properly. Second is a corresponding mechanism for appreciating conventional economics's fundamental assumptions from the Islamic point of view..$^{7} Q \bar{a} w a^{\prime} i d$ al-fiqhiyyah, as the basis for law-making rules, can dynamically follow the times by taking into account the social environment, including law and non-legal sciences, such as philosophy, history, sociology, and anthropology. Qāwa'id Al-Fiqhiyyah contains a set of fiqh rules used as a tool for the settlement of Islamic law. Most of these qawaid principles refer to the settlement of problems in the realm of muamalah or sharia economics. ${ }^{8}$ By applying qāwa'id al-fighiyyah into every attempt to make or interpret

5 Syamsul Hilal, "Qawâ‘Id Fiqhiyyah Furû‘Iyyah Sebagai Sumber Hukum Islam," AL-'ADALAH 11, no. 2 (2013): 141, https://doi.org/10.24042/adalah.v11i2.252.

6 Mohammad Hashim Kamali, Qawa 'id Al-Figh: The legal maxims of Islamic law (The Association of Muslim Lawyers, 2008): 1 .

7 Daud A. Mustafa, Hashir A. Abdulsalam, and Jibrail B. Yusuf, "Islamic Economics and the Relevance of AlQawāid Al-Fiqhiyyah," SAGE Open 6, no. 4 (October 2016):1, https:/ / doi.org/10.1177/2158244016671374.

8 Ro'is Alfauzi, "The Dynamics of Qawaid Fiqhiyyah: The Construction and Application In Islamic Law," Al-Bayyinah 4, no. 2 (October 12, 2020): 241, https:/ / doi.org/10.35673/al-bayyinah.v4i2.815. 
the law, it can be ascertained that law meets contemporary society standards, so it is not worried that the law would lead to new problems or a conflict of norms to apply. Islamic law and qāwa'id al-fiqhiyyah have an interrelationship with one another. This is because the dynamism of Islamic law embodied in fiqh is very dependent on qāwa'id al-fiqhiyyah. In this case, the generality or generality of the rules that make the Islamic law applicable to all conditions is the characteristic of the generality or generality of the rules. ${ }^{9}$

This research aims to see the suitability of Indonesia's prevailing laws and regulations with Islamic principles in protecting community property rights. The results of this research can be used as a reference in establishing laws and regulations concerning the Prohibition of Monopolistic Practices and Unfair Business Competition following Islam.

\section{MONOPOLY MARKET AND BUSINESS COMPETITION}

Etymologically, the word monopoly comes from Greek, from the word 'monos,' which means one, and 'polien' means the seller. ${ }^{10} \mathrm{~A}$ monopoly market is a form of interaction between supply and demand characterized by a single producer dealing with many consumers/ buyers. ${ }^{11}$ A monopoly market also means a form of market in which only one producer controls the market. ${ }^{12}$ The price maker in this market is a seller or often referred to as a "monopolist." As a price maker, a monopolist can increase or decrease the price by determining the number of goods produced. The fewer goods are produced, the more expensive the item, and vice versa. ${ }^{13}$

Meanwhile, business competition is an action to hinder or prevents competition. ${ }^{14}$ Business competition is an effort to pay attention to the advantages of each carried out by individuals or legal entities in the fields of trade, production, defense, and so on. ${ }^{15}$ This business competition will then give birth to a monopoly market.

9 Prawitra Thalib, “Application Of Qowaid Fiqhiyyah In Contemporary Islamic Law," Yuridika 31, no. 1 (January 28, 2016): 108, https:/ / doi.org/10.20473/ydk.v31i1.1958.

10 Aisyah Dinda Karina, "Praktik Monopoli Dan Persaingan Usaha Tidak Sehat Terhadap Pelaku Usaha Di Pasar Tradisional" 3, no. 2 (2019): 13.

11 Imamul Arifin, Ayatullah Khomaeni, dan Akbar Wahidin, Membuka Cakrawala Ekonomi (Bandung: PT. Setia Purna Inves, 2007): 54.

12 Mashur Malaka, "Praktek Monopoli dan Persaingan Usaha" 7, no. 2 (2014): 14; Ernethesia Jelita Aritonang, "Pengaruh Pasar Monopoli Di Indonesia," June 2020, 8.

13 Duwi Handoko, Ismail, dan Zulkifli Jasri, Hal-Hal Yang Dilarang Dalam Undang-Undang Anti Monopoli dan Persaingan Usaha Tidak Sehat (Universitas Islam Riau Fakultas Hukum, 2008): 12.

14 Meita Fadhilah, "Penegakan Hukum Persaingan Usaha Tidak Sehat Oleh Komisi Pengawas Persaingan Usaha (KPPU) Dalam Kerangka Ekstrateritorial," Jurnal Wawasan Yuridika 3, no. 1 (March 31, 2019): 55, https:// doi.org/10.25072/jwy.v3i1.217.

15 Maya Meilia and Darania Anisa, "Persaingan Usaha Tidak Sehat Di Indonesia Menurut Hukum Ekonomi Islam Dan Undang-Undang Nomor 5 Tahun 1999 Tentang Larangan Monopoli Dan Persaingan Usaha Tidak Sehat," El-JIZYA: Jurnal Ekonomi Islam, 1, 7 (2019): 27, http://ejournal.iainpurwokerto.ac.id/ index.php/eljizya/article/view/3446. 
The monopoly market has characteristics, among others: 1) a unique product that other companies cannot produce, so there are no substitute goods (close substitute) in the market; 2) there is only one company/ producer/ seller so that buyers cannot do anything other than buying/ use the product; 3 ) there are barriers to entry for other sellers, these barriers, including the legality, technology, and capital. ${ }^{16}$ Monopoly in the market can occur for several reasons, among others: First, the control of raw materials; Second, their mastery of specific production techniques; Third, their mastery of patents for specific products; Fourth, the existence of an institutionally obtained license; Fifth, a naturally obtained monopoly. ${ }^{17}$

Controlled by one producer in the market will harm consumers and other entrepreneurs. Impacts arisen are; 1) an increase in the price of goods and services causing inflation that is detrimental to the broader community; 2) an unreasonable profit for business actors due to the price mechanism determined arbitrarily by the producer; 3) the exploitation of consumers' purchasing power and no rights for consumers to vote to consume other goods; 4 ) production costs passed on to consumers by increasing prices; 5 ) the occurrence of an entry barrier, where similar companies will not be able to enter the market; and 6) creating unfair business competition and unequal income.

Law then regulates adverse effects occurring in the monopoly market. No. 5 of 1999 article 17 which says:

1. Business actors are prohibited from controlling the production and marketing of goods and services, resulting in monopolistic practices and unfair business competition.

2. Business actors suspected or deemed to control the production and or marketing of goods or services referred to in paragraph (1) if:

a. The goods and or services concerned have no substitute; or

b. Resulting in other businesses can not enter into the competition of goods and services the same; or

c. One business actor or a group of business actors controls more than $50 \%$ (fifty percent) of the market share of a specific type of goods or services.

Article 18 also regulates the adverse effects that occurred in the market monopsony, which says:

a. Business actors are prohibited from controlling the receipt of supplies

${ }^{6}$ Jun Surjanti, Musdholifah, dan Budiono, Edisi Belajar Teori Ekonomi (Pendekatan Mikro) Berbasis Karakter, 1 ed. (Yogyakarta: Deepublish, 2018): 30.

17 Ida Nuraini, Pengantar Ekonomi Mikro, 7 ed. (Malang: UMM Press, 2016): 108. 
Ahmad Lutfi Rijalul Fikri, Qawā'id al-Fiqhiyyah Analysis on the Prohibition of Monopoly Practices ...

or being the sole buyer of the goods or services in the relevant market, resulting in monopolistic practices and or unfair business competition.

b. Business actors should be suspected or deemed as controlling the receipt of supplies or become a single buyer as referred to in paragraph (1) if one business actor or a group of business actors controls more than $50 \%$ (fifty percent) of the market share of a specific type of goods or services.

This law includes explicitly several other objectives, including the protection of small and medium enterprises, or not encouraging an excessive concentration of economic power in the hands of a few market players, eliminating inefficient government regulations, and providing equal opportunities to compete and market entry. Law No. 5 of 1999, article 19 states that Business actors are prohibited from carrying out one or several activities, either alone or with other business actors, which may result in monopolistic practices and unfair business competition in the form of:

a. Refusing and or preventing certain business actors from carrying out the same business activities in the relevant market; or

b. Preventing consumers or customers of their business competitors from engaging in business relations with these business competitors; or

c. Restricting the distribution or sale of goods or services in the relevant market; or

d. We are conducting discriminatory practices against certain business actors.

Then in chapter 20, it says: "business actors are prohibited from supplying goods and or services utilizing selling at a loss or set a meager price with the intention of getting rid of or deadly business competitors in the relevant market which may result in monopolistic practices and or unfair business competition." Additionally, Article 21 says: "business actors are prohibited from committing fraud in determining production costs and other costs that are part of the components of the price of goods and or services which may result in unfair business competition." 18

Conspiracy in business is also a matter regulated in this Law. Article 22 says: "Business actors are prohibited from conspiring with other parties to regulate and or determine the tender winner, which may result in the unfair business competition." Additionally, Article 23 says: "Business actors are prohibited from conspiring with other parties to obtain information on their competitors' business activities which are classified as company secrets which may result in unfair business competition." Moreover, article 24 says: "Business actors are prohibited from conspiring with other parties to obstruct the

\footnotetext{
18 “Undang Undang Republik Indonesia," n.d., 50.
} 
production and or marketing of goods and or services of their competing business actors with the intention to the goods and or services offered or supplied in the relevant market are reduced in terms of quantity, quality or timeliness required." 19

Circumstances that are prohibited in this law, caused by the presence of a dominant position. The dominant position is the critical principle in competition law. Based on the dominant position's provisions, it can be stated that the business actor is engaging in monopolistic practices and or unfair business competition in the relevant market. Therefore, article 25, paragraph 1 states that business actors are prohibited from using a dominant position either directly or indirectly to:

a. Sets out the terms of trade to prevent and or prevent consumers from obtaining competitive goods and or services, in terms of both price and quality; or

b. Limit markets and technology development; or

c. Obstruct other business actors who have the potential to become competitors from entering the relevant market.

As a characteristic of the implementation and enforcement of competition law, the establishment of a supervisory committee can supervise the law's implementation. Various countries are enacting this legislation also establish a commission whose functions and authority adjusted to the legal system. The legal system regulated in a country provides different perspectives on the supervisory committee's position, function, and authority, which is an independent body.

Among the duties of the supervisory commission, as stated in article 35, are:

a) To conduct an assessment of the agreement which may result in monopolistic practices and or unfair business competition;

b) To conduct an assessment of business activities and or actions of business actors which may result in monopolistic practices and or unfair business competition;

c) To conduct an assessment of whether or not there is an abuse of a dominant position which may result in monopolistic practices and unfair business competition;

d) To take action following the Commission's authority;

e) To provide advice and considerations on Government policies related to monopolistic practices and or unfair business competition;

f) To develop guidelines and or publication related to this Law;

g) To provide regular reports on the work of the Commission to the President and the House of Representatives.

19 “Undang Undang Republik Indonesia." 


\section{QAW' $\bar{A}^{\prime} I D$ AL-FIQHIYYAH ABOUT THE MARKET MECHANISM}

As known that a market is a place where sellers and buyers meet to exchange benefits. Therefore, a regulatory framework is needed to protect the market from disturbing the market mechanism in the form of price games for goods and services or other things made to monopolize the circulation of goods and services. This regulatory framework should be a rule under the sharia law established by Allah and His Messenger. Among the framework rules are:

\section{A. Ihtikar}

The first qa'idah used in analyzing Law No. 5 of 1999 on the prohibition of لا يجتكر إلا خاطئ which means "monopoly is a mistake."

In language, احتكار means "collect food or the like then store it for sale when the price is high." ${ }^{21}$ As for احتكار in the term Jurisprudence (Figh), the Ulemas of Mazhab have different opinions about the definition. Ulemas of Hanafiyah say, "ihtikar/monopoly is buying food or the like and then storing it until the price becomes expensive."22 Ulemas of Mazhab Maliki define ihtikar as "storing goods for profit by selling them when the market situation is uncertain." 23 Ulemas of Mazhab Syafi'i say that "ihtikar/monopoly is buying goods at a low price and then save it from raising its prices." 24 Meanwhile, Ulemas of Mazhab Hanbali define that "ihtikar is buying goods (especially food) and storing them so that there are scarcity and price increases." 25

From the definitions stated above, it can be concluded that ihtikar/monopoly is storing goods or services then holding back the sale and distribution of goods or services to manipulate prices when consumer demand increases due to scarcity of goods where the rare goods have no substitute.

20 This rule ( $\left.q a^{\prime} i d a h\right)$ is derived from the hadith of the Prophet, from the history of Muammar bin Abdillah who said:

من دخل في شئ من أسعار المسلمين ليغليه عليهم، كان حقا على لله تعالى أن يقعده بطعام من النار يوم القيامة (anyone who plays something to raise prices for the Muslims, then Allah has the right to give him food from the fire later on the Day of Judgment).

Look, Abul Husain Muslim bin al-Hajjaj al-Qusyairi an-Naisaburi, Shahih Muslim, Juz 4 (Beirut: Dar ElFikr, 1992): 219; Sulaiman bin al-Asy'as bin Ishak bin Basyir bin Syidad bin Amar al-Azdi as-Sijistani, Sunan Abi Daud, Juz 3 (Beirut: al-Makmah al-'Ashriyyah, 1997): 1496; Abu Abdullah Muhammad bin Yazid bin Abdullah bin Majah Al Quzwaini, Sunan Ibnu Majah, Juz 3 (Beirut: Dar Al-Kutub Al-Ilmiyah, 1998): 558.

The same hadith is also a history of Umar bin Khattab saying:

$$
\text { من إحتكر على المسلمين طعاما ضربه الله بالجزام والإفلانس }
$$
(anyone who monopolizes the food of Muslims, then Allah will strike him with leprosy and bankruptcy).

21 'Athiyah 'Adlan 'Athiyah Ramdhan, Mausu'ah al Qawaid al Fiqhiyah (Damaskus: Dar al Aiman, 2007): 247.

22 Ibnu 'Abidin, Hasyiah Raddu al-Mukhtar 'Ala ad-Durri al-Mukhtar Syarh Tanwir al-Abshar Fiqh Abu Hanifah Ibnu Abidin, 2 (Beirut: Dar El-Fikr, 2000): 398.

23 Abu'l-Walid al-Baji, al-Muntaqa Sharh al-Muwatta, 5 (Mesir: Dar al-Kutub al-Islami, 1999): 15.

24 Abu Zakaria Muhyuddin bin Syaraf an-Nawawi, Al-Majmu'Syarh Al-Muhadzab Li Al-Syairazi, 1 (Jeddah: Maktabah Al-Irsyad, t.t.): 387.

25 Mansyur bin Yusuf bin Idris Al-Buhutiy, Kasyafal-Qanna' "An Matni al-Iqna," 3 (Lebanon: Dar Al-Kutub Al-Ilmiyah, 2009): 35. 
Ulemas of Mazhab also differ about the law of ihtikar/ monopoly. Jumhur Ulama of Hanafiyah and some of Jumhur Ulama of Syafi'iyah said that the ihtikar law is makruh tahrim ${ }^{26}$. They reasoned that the prohibition in the hadith because the impact is not merely the act of hoarding of goods and services. Meanwhile, Jumhur Ulama agreed that ihtikar is haram, and people who did this be punished for $\sin ^{27}$. They reasoned that it is an obligation to take legal action (forbidden) to eliminate the danger. ${ }^{28}$

From both legal opinions above, the opinion of Jumhur Ulama is the most reasonable. This is due to several reasons, among others:

1. the proposition in the hadith clearly says haram;

2. general texts in the hadiths prohibit tyranny against humans, including monopoly;

3. the opinion about the prohibition of monopoly is following the general rule in the hadith saying صرار ضار (must not do something that endangers yourself or others);

4. monopoly is the oppression and exploitation of the public because it affects the livelihood and viability;

5. forbid people to buy what they need is a tyranny because the market is where the buying and selling without dominance influence the balance of price and market mechanisms. ${ }^{30}$

According to the opinion of Jumhur Ulama, ihtikar/monopoly that is forbidden must meet several requirements, among others:

a. Ihtikar/monopoly on goods or services that can endanger the interests of the wider community and the State;

b. Ihtikar/ monopoly performed at the time of the scarcity of goods and services;

c. Ihtikar/ monopoly is conducted for purposes of profit at the time of scarcity.

26 Muhammad Fathi ad-Dariny, al-Figh al-Islam al-Muqarin ma'a al-Mazhab (Damaskus: Mansyurah Jami'ah, 1992): 90 .

27 Sulaiman Al-Bujairimy, Bujairimy 'Ala al-Khatib, 3 (Beirut: Dar El-Fikr, 2007): 255.

28 According to Majib Abu Rakhiyah, In essence, there is no difference between the opinions of the Ulama of Hanafi and Jumhur of Ulama. Because according to the mazhab hanafi makruh tahrim is something that when it is done gets sin, and if it is abandoned it gets the reward. Understanding Makruh Tahrim according to Mazhab Hanafi is exactly the sense Haram according to Jumhur of Ulama. Look, Muhammad Sulaima al-Asykar dkk., Buhuts al-Fiqhiyah fi Qhadaya Iqtishad Mu'asyirah (Urdun: Dar an-Nafais, 1998).

29 Ibnu Mâjah in the Kitab Al-Ahkâm, Bab Man banâ bihaqqihi mâ yadhurru jârahu, Hadith narrated by Ma'mar from Jabir from Ikrimah, No. 234. Look, Abu Abdullah Muhammad bin Yazid bin Abdullah bin Majah Al Quzwaini, Sunan Ibnu Majah (Beirut: Dar Al-Kutub Al-Ilmiyah, 1998): 353

30 'Athiyah 'Adlan 'Athiyah Ramdhan, Mausu'ah al Qawaid al Fighiyah (Damaskus: Dar al Aiman, 2007: 249-250. 
These requirements are made not to punish any monopoly as haram, because there is a kind of monopoly that should be applied the State monopolizes that for the welfare of his people. Therefore, Sharia authorizes the State to take measures considered as essential to control ihtikar/ monopoly. Among the preventive measures which fall under the authority of the State, among others:

1. make a foreclosure and selling monopoly goods; ${ }^{31}$

2. direct supervision of the prices of necessities;

3. staple goods storage policies for conducting market operations;

4. economic boycott, namely cutting off cooperation with monopolists. ${ }^{32}$

Based on the explanation above, it can be seen that the policies are taken by the government in Law no. 5 of 1999 Article 17 paragraph 1, which prohibiting business actors from controlling the production and marketing of goods and services, which may result in monopolistic practices and unfair business competition, are following this qawa'id fighiyyah. Likewise, the policies adopted by the government in the articles following prohibit control over goods or services that have no substitute for them, preventing other business actors from entering into the business competition, and controlling more than 50 percent of the market share of one type of goods and services; is following this qawa'id fiqhiyyah.

All of Ulemas also agreed that a monopoly is a form of oppression and exploitation of the public because it will affect the livelihood and agreed that a monopoly is a form of oppression and exploitation of the public. After all, it will affect the livelihood and viability of society. This prohibition is an effort to avoid domination that can affect price balance and market mechanisms that will lead to tyranny in the community. The government takes the policies in Law no. 5 of 1999 articles 18 and 19, which prohibit entrepreneurs from becoming sole suppliers or buyers who control more than 50 percent of the market share of a specific type of goods or services; prevent other business actors from doing the same business; hinder Cooperation between consumers and competing business actors; limit the circulation of goods and services, and practice of discrimination is the right policy and following the purpose of implementing this qawa'id fiqhiyyah.

\section{B. Najasy}

This fiqh rule of najasy says النجش حرام which means "buying and selling that contains elements of najasy is haram." The meaning of النجش / najasy is to increase the price of goods by people who do not want to buy to influence the price for

\footnotetext{
31 Ulama of Malikiyah, Syafiiyah, Hanabilah, and Hanafiyah say that Imam/ Judges may force monopolistic traders to sell their goods at a reasonable price. Look Muhammad Sulaiman al-Asykar etc., Buhuts alFiqhiyah fi Qhadaya Iqtishad Mu'asyirah (Urdun: Dar an-Nafais, 1998): 489-490.

32 al-Asykar, etc.: 489-493.
} 
other buyers (demand engineering). Others say that najasy selling contains fraud, cheating, and cunning that aim to harm others. ${ }^{33}$

This rule (qaidah) is derived from the hadith narrated by Ibn Umar saying:

$$
\text { في رسول الله صل الله عليه وسلم عن بيع النجش }
$$

"Rasulullah SAW prohibited the buying and selling of Najasy"34

From the hadith above, All of Ulemas conclude that buying and selling, categorized as najasy is haram. Imam as-Syaukani said that according to the Ulemas' agreement, buying and selling najasy is an act against the law (immoral). ${ }^{35}$

The purpose of this rule (qaidah) is to prohibit the seller from playing prices to cause harm to others. Under the policy taken by the government in Law No.5 of 1999, article 20, the purpose of this rule is to prohibits business actors from supplying goods or services by selling at a loss or setting low prices with the intention of getting rid of their competitors.

It is likewise in Article 21, which prohibits business actors from committing fraud in determining production costs and other costs into the price-forming components that may result in unfair business competition. However, it is likewise to the following three (3) articles which prohibit any conspiracy that could unfairly influence prices resulting in unfair business competition.

\section{Tas'ir}

According to Majid, the term التسعير/price-fixing is essential, and it is the government's decision to sellers not to sell their merchandise except at a predetermined price. ${ }^{36}$ Meanwhile, according to 'Athiyah, التسعير/ price-fixing is the government's decision to determine prices for necessities (goods and services) and to force them to sell according to predetermined prices. ${ }^{37}$

Tas'ir/ price-fixing is something that is prohibited in Islam. ${ }^{38}$ However, this prohibition only applied when market conditions are expected, and there is no

33 Muhammad Abdurrauf Al-Manawi, Faydul Al-Qadir Syarh Al-Jami' As-Shaghir, 6 (Beirut: Dar Al-Kutub Al-Ilmiyah, 2001): 419.

34 Muhammad bin Ismail Al-Bukhari, Shahih Bukhari (Damaskus: Dar Ibnu Katsir, 2002), 515.

35 Ramdhan, Mausu'ah al Qawaid al Fighiyah: 258.

36 al-Asykar dkk., Buhuts al-Fiqhiyah fi Qhadaya Iqtishad Mu'asyirah: 365.

37 Ramdhan, Mausu'ah al Qawaid al Fiqhiyah: 261.

38 This prohibition is based on the hadith of the Prophet Muhammad SAW, which was narrated by Anas who said:

قال "غلا السعر في المدينة، علي عهد رسول الله، فقال الناس: يا رسول الله، غلا السعر فسعر لنا، فقال رسول الله صل الله عليه وسلم

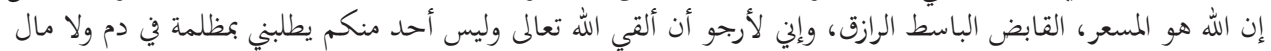
"There has been an increas in prices of goods at the time of the Prophet Muhammad, then people said to Rasulullah: O Rasulullah there has been an increase in prices, so set a price for us. Rasulullah SAW said: "Verily Allah has the right to set prices, the Supreme Narrowing Rizki, Supreme Expanding Rizki, Supreme confer Rizki. Truly I hope to meet Allah in a situation that none of you demands of me (in front of Allah) because of an injustice that I have done to you, related to blood and property".

Look, as-Sijistani, Sunan Abi Daud, Kitabul Buyu> Bab fi Tas>ir, No.rosı; Quzwaini, Sunan Ibnu Majah, Kitab at-Thaharah, No. r...; Hanbal, Musnad Ahmad bin Hanbal, No. rлr. 
monopoly by sellers to get more profit and harm consumers. ${ }^{39}$ This price-fixing is considered very important because the general rules (Qawa'id al-'Ammah) in Islamic law stipulated that everything related to market mechanisms must be based on the principles of goodness and justice for sellers' buyers.

Although price-fixing is considered very important in uncertain market conditions, however, Ulemas still differs on this issue. Here are the differences in Ulemas opinions and their reasons:

First: All Ulemas from the Syafi'iyah, Hanabilah, and some Malikiyah said that tas'ir/price-fixing is prohibited despite a market imbalance. They reasoned with a hadith narrated by Imam Malik in the book Muwatho' which is derived initially from Abu Hurairah said:

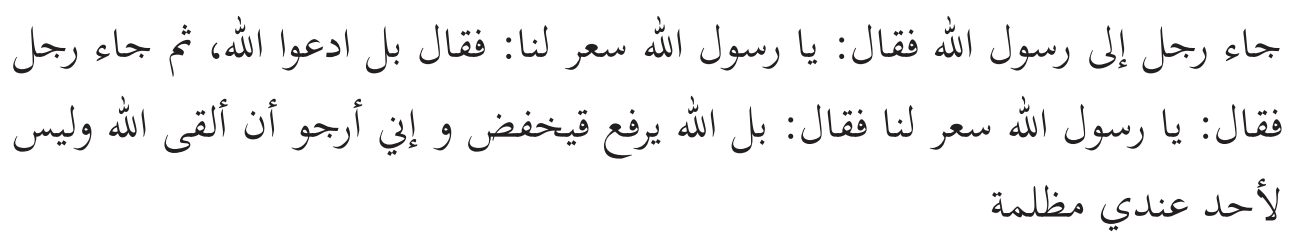

"A man came to Rasulullah SAW saying: "O Rasulullah set a price for us." Then the Prophet said: "Ask you to Allah." Then another man came and said: "O Rasulullah set a price for us." then, the Prophet said: "Allah who raises prices and decreases prices, I want to face Allah, and none of the injustice is with me." 40

Imam Syafi'i says that humans have the right to complete mastery of their property. No one can take that right without his willingness - except in matters that indeed they had an obligation there - and price-fixing is not included in the exclusion. ${ }^{41}$ Muhammad Al-Khatib also followed the opinion of the Imam Shafi'i. He said that government policy in terms of price-fixing is haram, even though at the time the price increases, this action is a form of oppression to the seller. ${ }^{42}$

Second: All of Ulemas of Hanafiyah, some of Ulemas of Malikiyah, and Ibn Taymiyyah from Ulemas of Muta'akhirin said that the government should do tas' $i r$ / price-fixing in case of market imbalance. The reason for the permissibility, among others:

1. the government is not allowed to set prices except when staple foods' price is not reasonable. The government is unable to protect the basic needs of Muslims except by fixing prices. Such a situation is allowed after consultation with experts in economics. ${ }^{43}$

\footnotetext{
39 Ahmad bin Abdul Halim bin Taimiyah, Al-Hisbah Fi Al-Islam (Lebanon: Dar Al-Kutub Al-Ilmiyah, t.t.): 39-40.

40 Al- Baaji, Al-Muntaqa Sharh al-Muwatta, vol. 5 (Kairo: Dar Al-Kutub Al-Ilmiyah, n.d.), 18.

${ }^{41}$ al-Asykar dkk., Buhuts al-Fighiyah fi Qhadaya Iqtishad Mu'asyirah: 373.

42 Muhammad bin Muhammad Al-Khatib, Mugni Al-Muhtaj Ila Ma'rifati Ma'ani Alfaz Al-Minhaj, III (Beirut: Dar Al-Kutub Al-Ilmiyah, 2000): 392.

43 Nizam dan Hasan bin Mansyur al-Auzajandy, Fatawa Al-Hindiyah fi Mazhabi al-Imam Abi Hanifah (Mesir: Al-Mathba'ah Al-Amiriyah, 1310): 214.
} 
2. After explaining the hadith from Anas, Ibn' Arabi Al-Maliki said: "Price fixing is carried out when there is the fear of entrepreneurs who aim to destroy Muslim property."44

3. Imam Ibn Taymiyyah said in the book Al-Hisbah: "For example, the owner of the goods does not want to sell his goods when the community needs them, except by raising the price higher than the normal price. So in these circumstances, it is obligatory for the owner of the goods to sell them fairly. The meaning of tas'ir / fixing price is obliging the owner of the goods to sell at a fair price, as required by Allah to do so". ${ }^{45}$

Imam Ibn Qayyim said:

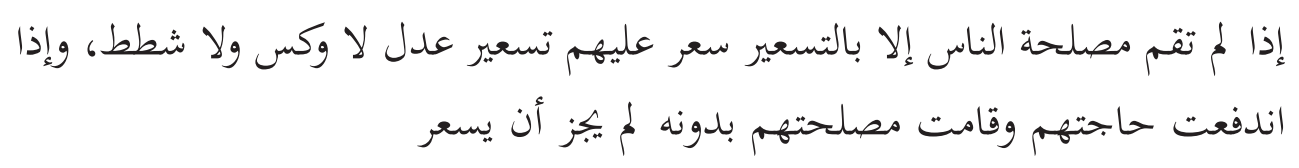

"If the interests of the people cannot be achieved except by price-fixing, then the government must set prices fairly, not reducing and not exaggerating. If there are other ways to solve it, the price-fixing by the government is not allowed." 46

Although we see that there are differences of opinion from the Ulemas about whether or not the government should decide/ fix the price of necessities, the scholars agreed that price-fixing should not be carried out to oppress consumers. This objective is what we see in the government's policies in Law no. 5 of 1999 on the Prohibition of Monopolistic Practices and Unfair Business Competition in article 25, which prohibits business actors from using a dominant position directly or indirectly, which may result in unfair business competition.

From the explanation of the three qawa'id fighiyyah and the purpose of the formation of these qaidahs, the government is right in making laws and regulations following the Maqāshid Shari'a, namely how to protect community property rights to be not exploited by a group of people who are not responsible for controlling market mechanisms. Conformity of legislation with Maqāshid Shari'a also needs to be maintained in the Draft Law on the Prohibition of Monopolistic Practices and Unfair Business Competition programmed by the House of Representatives (DPR).

\section{CONCLUSION}

With all its provisions and regulations, Islam recognizes individual ownership during the process of obtaining it following the rules of the Sharia. Islam also allows individuals to transact their assets as long as the transaction is in line with the Sharia spirit and does not conflict with the people's welfare.

44 Ibnu 'Arabi, 'Aridhatul Ahwazy bi Syarhi Shahih At-Thirmizi (Lebanon: Dar Al-Kutub Al-Ilmiyah, 2008): 54.

45 Taimiyah, Al-Hisbah Fi Al- Islam: 22.

46 'Athiyah 'Adlan 'Athiyah Ramdhan, Mausu'ah al Qawaid al Fiqhiyah (Damaskus: Dar al Aiman, 2007), 260. 
Ahmad Lutfi Rijalul Fikri, Qawā'id al-Fiqhiyyah Analysis on the Prohibition of Monopoly Practices ...

The Ulemas then formulate these Sharia rules in the form of rules of fiqh principles (qawa'id fighiyyah) to regulate the balance between individual and public interests based on the texts of the Qur'an and the Hadith of the Prophet, which prohibits acts of injustice such as the prohibition ihtikar/ monopoly, the prohibition najasy/ demand engineering, and tas'ir prohibitions/ price-fixing.

Refers to the three rules ( $q a w \bar{a}^{\prime} i d$ ) above, the policies taken by the government under Law No. 5 of 1999 on the Prohibition of Monopolistic Practices and Unfair Business Competition containing the prohibition of control over the production and marketing of goods and services, prohibition of committing fraud or conspiracy, and the prohibition to use the dominant position, where all these prohibitions lead to unfair business competition in the market following the fiqh principles established by the Ulemas derived from the Qur'an and Hadith.

\section{REFERENCES}

'Abidin, Ibnu. Hasyiah Raddu Al-Mukhtar 'Ala Ad-Durri al-Mukhtar Syarh Tanwir al-Abshar Figh Abu Hanifah Ibnu Abidin. 2. Beirut: Dar El-Fikr, 2000.

Al- Baaji. Al-Muntaqa Sharh al-Muwatta. Vol. 5. Kairo: Dar Al-Kutub Al-Ilmiyah, n.d.

Al-Buhutiy, Mansyur bin Yusuf bin Idris. Kasyaf Al-Qanna' "An Matni al-Iqna." 3. Lebanon: Dar Al-Kutub Al-Ilmiyah, 2009.

Al-Bujairimy, Sulaiman. Bujairimy 'Ala al-Khatib. 3. Beirut: Dar El-Fikr, 2007.

Al-Bukhari, Muhammad bin Ismail. Shahih Bukhari. Damaskus: Dar Ibnu Katsir, 2002.

Alfauzi, Ro'is. "The Dynamics of Qawaid Fiqhiyyah: The Construction and Application In Islamic Law." Al-Bayyinah 4, no. 2 (October 12, 2020): 225-42. https://doi.org/10.35673/al-bayyinah.v4i2.815.

Al-Khatib, Muhammad bin Muhammad. Mugni Al-Muhtaj Ila Ma'rifati Ma'ani Alfaz Al-Minhaj. III. Beirut: Dar Al-Kutub Al-Ilmiyah, 2000.

Al-Manawi, Muhammad Abdurrauf. Faydul Al-Qadir Syarh Al-Jami' As-Shaghir. Beirut: Dar Al-Kutub Al-Ilmiyah, 2001.

'Arabi, Ibnu. 'Aridhatul Ahwazy Bi Syarhi Shahih At-Thirmizi. Lebanon: Dar AlKutub Al-Ilmiyah, 2008.

Arifin, Imamul, Ayatullah Khomaeni, and Akbar Wahidin. Membuka Cakrawala Ekonomi. Bandung: PT. Setia Purna Inves, 2007.

Aritonang, Ernethesia Jelita. "Pengaruh Pasar Monopoli Di Indonesia," June 2020,8 .

Asykar, Muhammad Sulaiman al-, Muhammad Utsman Syabir, Majid Muhammad Abu Rakhiyah, and Umar Sulaiman al-Asykar. Buhuts Al-Fiqhiyah Fi Qhadaya Iqtishad Mu'asyirah. Urdun: Dar an-Nafais, 1998. 
Baji, Abu'1-Walid al-. Al-Muntaqa Sharh al-Muwatta. 5. Mesir: Dar al-Kutub alIslami, 1999.

Dariny, Muhammad Fathi ad-. Al-Figh al-Islam al-Muqarin Ma'a al-Mazhab. Damaskus: Mansyurah Jami'ah, 1992.

DJKN. “Intervensi Pemerintah Dalam Perekonomian: Bagian I Ringkasan Sejarah," April 20, 2018. https://www.djkn.kemenkeu.go.id/artikel/baca/12670/ Intervensi-Pemerintah-Dalam-Perekonomian-Bagian-I-Ringkasan-Sejarah. html.

Fadhilah, Meita. "Penegakan Hukum Persaingan Usaha Tidak Sehat Oleh Komisi Pengawas Persaingan Usaha (KPPU) Dalam Kerangka Ekstrateritorial." Jurnal Wawasan Yuridika 3, no. 1 (March 31, 2019): 55. https:// doi. org/10.25072/jwy.v3i1.217.

Hanbal, Ahmad bin. Musnad Ahmad Bin Hanbal. Beirut: Muassasah al-Risālah, 2001. Handoko, Duwi, Ismail, and Zulkifli Jasri. Hal-Hal Yang Dilarang Dalam UndangUndang Anti Monopoli Dan Persaingan Usaha Tidak Sehat. Universitas Islam Riau Fakultas Hukum, 2008.

Hilal, Syamsul. "Qawâ‘'Id Fiqhiyyah Furû‘ Iyyah Sebagai Sumber Hukum Islam." AL-'ADALAH 11, no. 2 (2013): 141-54. https:// doi.org/10.24042/adalah. v11i2.252.

Kamali, Mohammad Hashim. Qawa 'id Al-Figh: The Legal Maxims of Islamic Law. The Association of Muslim Lawyers, 2008.

Karim, Adiwarman A. Ekonomi Mikro Islami. Jakarta: Rajawali Pers, 2010.

Karina, Aisyah Dinda. "Praktik Monopoli Dan Persaingan Usaha Tidak Sehat Terhadap Pelaku Usaha Di Pasar Tradisional" 3, no. 2 (2019): 13.

Malaka, Mashur. "Praktek Monopoli dan Persaingan Usaha" 7, no. 2 (2014): 14. Marni, Sumarni. "'Intervensi Pemerintah" Antara Kebutuhan Dan Penolakan Di Bidang Ekonomi." Economica 1, no. 2 (May 21, 2015): 183-94. https:// doi. org/10.22202/economica.2013.v1.i2.118.

Maya Meilia and Darania Anisa. "Persaingan Usaha Tidak Sehat Di Indonesia Menurut Hukum Ekonomi Islam Dan Undang-Undang Nomor 5 Tahun 1999 Tentang Larangan Monopoli Dan Persaingan Usaha Tidak Sehat." El-JIZYA: Jurnal Ekonomi Islam, 1, 7 (2019). http:/ / ejournal.iainpurwokerto. ac.id/index.php/eljizya/article/view/3446.

Mustafa, Daud A., Hashir A. Abdulsalam, and Jibrail B. Yusuf. "Islamic Economics and the Relevance of Al-Qawä'id Al-Fiqhiyyah." SAGE Open 6, no. 4 (October 2016): 215824401667137. https:// doi.org/10.1177/2158244016671374.

Naisaburi, Abul Husain Muslim bin al-Hajjaj al-Qusyairi an-. Shahih Muslim. Beirut: Dar El-Fikr, 1992. 
Ahmad Lutfi Rijalul Fikri, Qawā’id al-Fiqhiyyah Analysis on the Prohibition of Monopoly Practices ...

Nawawi, Abu Zakaria Muhyuddin bin Syaraf an-. Al-Majmu'Syarh Al-Muhadzab Li Al-Syairazi. 1. Jeddah: Maktabah Al-Irsyad, n.d.

Nizam and Hasan bin Mansyur al-Auzajandy. Fatawa Al-Hindiyah Fi Mazhabi alImam Abi Hanifah. Mesir: Al-Mathba'ah Al-Amiriyah, 1310.

Nuraini, Ida. Pengantar Ekonomi Mikro. 7th ed. Malang: UMM Press, 2016.

Quzwaini, Abu Abdullah Muhammad bin Yazid bin Abdullah bin Majah Al. Sunan Ibnu Majah. Beirut: Dar Al-Kutub Al-Ilmiyah, 1998.

Rahardja, Pratama, and Mandala Manurung. Teori Ekonomi Mikro Suatu Pengantar. IV. Jakarta: LPFEUI, 1999.

Ramdhan, 'Athiyah 'Adlan 'Athiyah. Mausu'ah al Qawaid al Fiqhiyah. Damaskus: Dar al Aiman, 2007.

Ramdhan, 'Athiyah 'Adlan 'Athiyah. Mausu'ah al Qawaid al Fiqhiyah. Damaskus: Dar al Aiman, 2007.

Sijistani, Sulaiman bin al-Asy'as bin Ishak bin Basyir bin Syidad bin Amar al-Azdi as-. Sunan Abi Daud. Beirut: al-Makmah al-'Ashriyyah, 1997.

Surjanti, Jun, Musdholifah, and Budiono. Edisi Belajar Teori Ekonomi (Pendekatan Mikro) Berbasis Karakter. 1st ed. Yogyakarta: Deepublish, 2018.

Taimiyah, Ahmad bin Abdul Halim bin. Al-Hisbah Fi Al-Islam. Lebanon: Dar AlKutub Al-Ilmiyah, n.d.

Thalib, Prawitra. "Application of Qowaid Fiqhiyyah In Contemporary Islamic Law." Yuridika 31, no. 1 (January 28, 2016): 54. https:/ / doi.org/10.20473/ ydk.v31i1.1958. 